\title{
NEW DIMENSIONS OF TEACHING AND LEARNING "BY DOING" IN THE GLOBAL CONTEXT OF EDUCATION
}

\section{Daniela Tamo, Aljula Jubani, Mimoza Gjokutaj}

Tirana University, Albania

E-mail: danielatamo@gmail.com, aljulajubani@yahoo.com,

mgjokutaj@yahoo.com

\begin{abstract}
Efforts are being made in many educational settings to find out the most effective ways of assuring quality of the teaching and learning process. In the framework of continuous reformation of the education system in Albania, many initiatives have been taken aiming at improving the quality of the teaching and learning process WHERE?? IN THE AREA OF???? . Several ambitious projects have been piloted. One of them is related to setting the teaching and learning process in a pragmatic global context. This project was piloted in some areas of Albania. It aimed at applying some new principles of teaching and learning by simultaneously setting teaching and learning in four dimensions: that of time (present, past, future), space, problems (environment, human rights, etc.) and internal. Teaching was based on the use of interactive, all inclusive techniques and strategies. As a result, the interactive profile of the teacher is strengthened and the quality of students'learning has improved as well. This project is supported by the Institute of Global Education in Canada

This article brings a picture of the impacts of this initiative, which are related with the best student outcomes, change of values and attitudes about life, new approaches for the world and the active participation in important social roles. This pilot work has led to a new objective, namely the one of establishment of a new teacher profile in the global area and of the new roles it should take in the course of both teaching and learning. Data and thoughts of teachers and students related to such findings are described in the current article.
\end{abstract}

Key words: dimensions, Global Education, new pilot, principles, quality.

\section{Introduction}

Numerous steps have been taken in the Albanian education system to adopt the Albanian schools to the current and future needs of individuals, groups, and the society in general. Contemporary teaching approaches like "critical thinking", "step by step philosophy" and other renowned practices have become part of the positive movements of the Albanian education.

\section{Problem of Research}

Global education as such is the subject matter of this research work. It provides a process of change in the teaching and learning domain. 
PROBLEMS

OF EDUCATION

IN THE $21^{\text {st }}$ CENTURY

Volume 44, 2012

82

\section{Research Focus}

A pilot project on Global Education was introduced in the Albanian school practice during the period of 1998-2008. The project was assisted by the International Institute for Global Education of Toronto, and was supported by UNICEF. In the long-term, the philosophy of Global Education in Albania aimed at addressing two levels: at designing and at creating a global curriculum, capable of reflecting the world's dynamic globalism, and the qualification of teachers, so that they can learn and teach others in a constantly changing world through an interactive and all-inclusive learning process.

The Albanian National Strategy for Pre-University Education Development 20042015, includes the philosophy of Global Education. The dimensions of Global Education are therefore officially introduced in the official school curriculum, and in the learning and teaching methodologies (National Strategy for Education 2000-2015).

Considering the values and the impact this project had on the performance of schools and teachers, the Ministry of Education and Science, recommended that the principles and methodologies of this philosophy be also introduced in the curriculum of pedagogic preuniversity and university institutions. In this context, preparation of teachers with the Global education principles and philosophy served to creating student-centered teaching models.

Given the above findings about the philosophy of Global Education, there is now a strong belief that such a teaching model and practice has a significant impact on the quality of the school curriculum and daily teaching practice, making them more coherent and flexible.

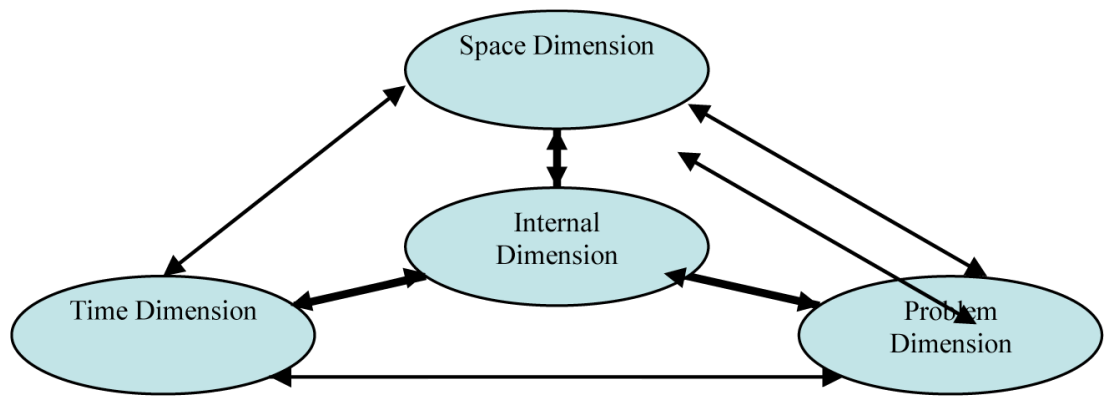

Figure 1. Global Education.

The space dimension shows the increasing global interdependence and the systemic nature of today's world, which is being transformed into a collection of places and peoples in a system of places and peoples.

The time dimension presents the dynamic relationship between the past, the present, and the future, where the future takes a central place.

The internal dimension shows that the curriculum and activities built for purposes of reaching these objectives give the internal world an equally central role with the external world, as the increase of knowledge about the world goes hand in hand with the increase of selfawareness.

The problem dimension, as another dimension of Global Education, gives students an opportunity to learn about main global issues like development, environment, peace, rights, discrimination, poverty, and social, economic, and political crisis, etc.

Based on the understanding of these dimensions of Global Education, the research explores successful teaching strategies and techniques. Some of the techniques at the didactic level, whose effects were explored, included listening skills, attention skills, follow-up skills, 
Daniela TAMO, Aljula JUBANI, Mimoza GJOKUTAJ. New Dimensions of Teaching and Learning "By Doing" in the Global Context of Education

reflection skills, all-inclusive skills, as well as discussions through methods like brainstorming, role play, group work, devil's advocate, discussion circle, simulation, mapping, problem solution, case studies, etc.

The research explores the value of models created for different subjects. They include one or two of the above-mentioned dimensions, enriched through the model lesson scheme. The research includes lesson models and explores their value in terms of their timeframe, objectives, means, resources, potential, structure, steps, variation, etc. The research also studies the effectiveness of topics like: interdependence and relationships in the community, region, and among people; democratic citizenship education; human rights and responsibilities education; peace education; conflict resolution; environment and health; social and economic education; discrimination; future thinking; personal, local, national, regional, and global future; self-evaluation and self-awareness; and the intellectual, emotional, spiritual, and physical completion, etc.

\section{Methodology of Research}

\section{General Background of Research}

As it was mentioned above, research into the Global Education philosophy and its introduction in the school practice, was a process that was well spread both in a wide educational space, and in sufficient time to identify its value, advantages, and impact on teaching. Thus, the research process involved curriculum experts for subjects like: Albanian language, mathematics, history, geography, and civic education.

\section{Sample of Research}

The sample of the research was 10 curricula experts, 30 teachers from four different regions of Albania, i.e. Shkodra, Tirana, Durrës, and Elbasan, 10 school directors, about 3000 students each year, 300 lesson units designed by the experts.

\section{Instrument and Procedures}

Instruments used in this study are the direct observations of experts, structured interviews with teachers prior to their engagement with global education specific activities in the classroom and after these activities, questionnaire with teachers and students and school directors, note taking in the form of the diary, feedback at the end of the piloting of the activity. Such instruments are used both before and after piloting of model lessons, enabled for the analyzing work, discussions and the outcomes of the research.

At the beginning of the process the 10 curricula experts and 30 teachers went first through some training courses based on the philosophy of Global Education. Each training course took several days, and training was delivered by Canadian and Albanian trainers. Afterwards, the experts set the curricula fields and lines of intervention, prepared the model lessons, discussed about them prior to approval by the working group. The experts observed the entire process, including the implementation of the pilot projects too.

\section{Results of Research}

The answers provided below have come as a result of the collection and processing of the data and instruments used by teachers and students. 
PROBLEMS

OF EDUCATION

IN THE $21^{\text {st }}$ CENTURY

Volume 44, 2012

84
Results of the Interviews

Table 1. Interview 1: Answers of the interview with the 30 teachers before the test.

\begin{tabular}{|c|l|l|}
\hline \multicolumn{1}{|c|}{ Questions } & \multicolumn{1}{|c|}{ Teachers' answers } \\
\hline 1. & $\begin{array}{l}\text { In your opinion, which are the most important } \\
\text { qualities of a teacher? }\end{array}$ & $\begin{array}{l}\text { Scientific accuracy, clarity, enthusiasm, management and } \\
\text { evaluation skills }\end{array}$ \\
\hline 2. & $\begin{array}{l}\text { What is your opinion about the seminars you } \\
\text { have attended? }\end{array}$ & Indispensable, successful, well received, delayed \\
\hline 3. & $\begin{array}{l}\text { Do you consider preliminary preparation for } \\
\text { testing the activities useful? }\end{array}$ & $80 \%$ of the teachers consider it sufficient enough \\
\hline 4. & $\begin{array}{l}\text { In your opinion, do the activities serve for } \\
\text { reaching the curricula objectives? }\end{array}$ & $100 \%$ \\
\hline 5. & $\begin{array}{l}\text { Which are your initial expectations and } \\
\text { concerns for the conduct of activities in the } \\
\text { classroom? }\end{array}$ & $\begin{array}{l}\text { Expectations: professional expectations, quality, enthusiasm } \\
\text { Concerns: time, class management }\end{array}$ \\
\hline 6. & $\begin{array}{l}\text { Which will be the changes in the class during } \\
\text { the piloting? }\end{array}$ & $\begin{array}{l}\text { Cooperation and positive spirit of the students in their learning, } \\
\text { independence, freedom, quality, self-control }\end{array}$ \\
\hline 7. & $\begin{array}{l}\text { How will the students' answers be in the } \\
\text { activities? }\end{array}$ & $\begin{array}{l}85 \% \text { of the teachers think accurate } \\
15 \% \text { of the teachers think unclear. }\end{array}$ \\
\hline 8. & $\begin{array}{l}\text { Describe what do you understand with Global } \\
\text { Education? }\end{array}$ & $\begin{array}{l}\text { A new form of teaching based on a variety of global issues, } \\
\text { with strategies and techniques that enable the meeting of } \\
\text { objectives at a high learning level }\end{array}$ \\
\hline
\end{tabular}

Table 2. Interview 2: Answers of the interview with the $\mathbf{3 0}$ teachers after the test.

\begin{tabular}{|c|c|c|}
\hline & Questions & Teachers' answers \\
\hline 1 & What do you think about the tests? & $\begin{array}{l}100 \% \text { of teachers think that the tests were successful in the } \\
\text { teaching process. }\end{array}$ \\
\hline 2 & $\begin{array}{l}\text { Have you faced with obstacles or difficul- } \\
\text { ties? If yes, which were they? }\end{array}$ & $\begin{array}{l}\text { Yes, the use of the didactic means, organization of the group } \\
\text { work, insufficient time. }\end{array}$ \\
\hline 3 & In which directions were the tests most & Clarity of the steps and objectives. \\
\hline 4 & $\begin{array}{l}\text { In which directions were the tests less } \\
\text { successful? }\end{array}$ & $\begin{array}{l}\text { Some of the tests were long with many steps and were not suit- } \\
\text { able to the time available. }\end{array}$ \\
\hline 5 & $\begin{array}{l}\text { Have the students' attitudes on the activi- } \\
\text { ties changed during the piloting period? }\end{array}$ & $\begin{array}{l}100 \% \text { of the teachers answered YES. The activities are better } \\
\text { organized, the results are better; there is more cooperation and a } \\
\text { better inclusion. }\end{array}$ \\
\hline 6 & $\begin{array}{l}\text { Did piloting influence the teaching proc- } \\
\text { ess? Provide an explanation. }\end{array}$ & $\begin{array}{l}100 \% \text { of the teachers answered YES. } \\
\text { Now teaching is student centered; students do the job and the } \\
\text { teacher leads and guides the process. }\end{array}$ \\
\hline 7 & $\begin{array}{l}\text { Did you inform your colleagues about the } \\
\text { piloted activities? How did you do this? } \\
\text { Which was the result? }\end{array}$ & $\begin{array}{l}100 \% \text { of the teachers answered YES. The colleagues were in- } \\
\text { terested to know more, and they are reported of having attended } \\
\text { our classes. Some colleagues were jealous for not participating } \\
\text { in this change. }\end{array}$ \\
\hline 9 & $\begin{array}{l}\text { If you have to describe piloting experience } \\
\text { using only four words, which are they? }\end{array}$ & Successful, necessary, mobilizing and challenging \\
\hline 10 & $\begin{array}{l}\text { If you repeat the piloted activities, which } \\
\text { are the changes you'd made? }\end{array}$ & $\begin{array}{l}\text { There is room for change, for better planning in line with the time } \\
\text { available. }\end{array}$ \\
\hline 11 & $\begin{array}{l}\text { Before the piloting, you identified some of } \\
\text { the expectations and concerns. Are they } \\
\text { met? }\end{array}$ & $\begin{array}{l}\text { Expectations are realized by } 70-80 \% \\
\text { Concerns are justified by } 90 \%\end{array}$ \\
\hline
\end{tabular}


Daniela TAMO, Aljula JUBANI, Mimoza GJOKUTAJ. New Dimensions of Teaching and Learning "By Doing" in the Global Context of Education

\section{Results of the Questionnaires}

Answers of the questionnaire for 30 teachers before the test

1. List the five most important qualities that a teacher dealing with the Global Education activities should have.

Well-prepared, creative, open, cooperative and enthusiastic.

2. Write three comments that summarize your impressions on the seminars you have taken part in.

They were interesting, brought about new things as regards teaching and should be organized more often.

3. In your opinion, which is the quality of the activities? Circle the number that shows your opinion.

Very well prepared 50\%; Well prepared 50\%; Sufficiently prepared 0; Not well prepared 0; Badly prepared 0.

4. Which are your expectations and concerns on piloting? Mention three of them.

$$
\text { Expectations Concerns }
$$

Better quality of learning; step by step conduct of the objectives;

New spirit of cooperation; time management;

Creativity. the work of the students with the problems.

5. Which will be the attitude of the students towards the activities? Circle the number that shows your opinion.

Very positive - 100\%; Positive - 0; Undefined - 0; Negative - 0; Very negative - 0.

Answers of the questionnaire for 30 teachers after the test

1. How much successful were the piloted activities? Circle the number that shows your opinion and explain the answer.

Very well prepared-50\%; Well prepared-50\%; Sufficiently prepared-0; Not well prepared-0; Badly prepared-0.

2. Write words that summarize the value of activities:

Clear, scientifically accurate, accompanied with interactive techniques and strategies for every step, satisfactory.

3. Were there obstacles in the classroom, or in the school that have made it difficult for you to carry out the piloting phase? If yes, please describe them.

Often the directors of the school did not understand the activities. That's why they were asked to take part in the trainings and became part of the project. Even the teachers who did not participate in the project had some prejudice.

4. Which was the attitude of the students towards the activities? Circle the number that shows your opinion.

Very positive-90\%; Positive-10\%; Undefined-0; Negative-0\% Very negative-0\%.

5. In your opinion, at what level the activities have met the objectives of the curricula? Circle the number that shows your opinion.

\begin{tabular}{|c|c|c|c|c|}
\hline Very successful & Successful & Sufficient & Not successful & Not at all successful \\
5 & 4 & 3 & 2 & 1 \\
\hline
\end{tabular}


PROBLEMS

OF EDUCATION

IN THE $21^{\text {st }}$ CENTURY

Volume 44, 2012

86

6. If you repeat the piloting activities, will you make any changes to the activities? 90\% of the teachers answered A little; $10 \%$ of the teachers answered $\mathrm{No}$

Table 3. Observations by the experts.

\begin{tabular}{|c|c|}
\hline Issues observed & Notes by the observers \\
\hline $\begin{array}{l}\text { Explanation of the activity } \\
\text { Did all or the majority of the students understand the } \\
\text { procedure clearly? } \\
\text { Were all the necessary clarifications given? }\end{array}$ & $\begin{array}{l}\text { The teachers explained the procedure clearly. The majority } \\
\text { of students understand the procedure and activities that will } \\
\text { carry out. The teachers provide clear explanations at the } \\
\text { beginning of the process and during the process. }\end{array}$ \\
\hline $\begin{array}{l}\text { Resources } \\
\text { Are there all the necessary resources (including the } \\
\text { space of the classroom)? Are they suitable? }\end{array}$ & $\begin{array}{l}\text { There are the necessary resources in the classroom. } \\
\text { Sometimes the space within the classroom is not sufficient } \\
\text { enough. }\end{array}$ \\
\hline $\begin{array}{l}\text { Students' skills } \\
\text { Do the students have the necessary knowledge and } \\
\text { skills to conduct the activity successfully? }\end{array}$ & $\begin{array}{l}\text { There are a great number of students with sufficient knowl- } \\
\text { edge for carrying out the activity. }\end{array}$ \\
\hline $\begin{array}{l}\text { Students' inclusion } \\
\text { Are all the students or the majority of them involved } \\
\text { actively in each part of the activity? }\end{array}$ & $\begin{array}{l}95 \% \text { of the students are involved actively in carrying out the } \\
\text { activity. }\end{array}$ \\
\hline $\begin{array}{l}\text { Changes in the activities } \\
\text { Are there changes or adaptations made in the activ- } \\
\text { ity? } \\
\text { Are there other phases added or omitted from the } \\
\text { activity? }\end{array}$ & $\begin{array}{l}\text { Initiatives of the teachers to make changes in the activities } \\
\text { are sometimes observed, but they are not very often. }\end{array}$ \\
\hline $\begin{array}{l}\text { Time } \\
\text { Is time sufficient, insufficient or more than necessary } \\
\text { to complete all the phases of the activity (including } \\
\text { the descriptive summary)? }\end{array}$ & $\begin{array}{l}\text { In general, the teachers say that the time is insufficient. } \\
\text { They have to plan for more time. They haven't shortened the } \\
\text { activity because the students themselves did not accept this } \\
\text { thing. The students wanted to complete the activity. }\end{array}$ \\
\hline $\begin{array}{l}\text { Direction teacher - student (summary) } \\
\text { - What percentage of the lesson is led by the } \\
\text { teacher? } \\
\text { What percentage of the lesson is led by the } \\
\text { student? } \\
\text { What percentage of the lesson is spent by the } \\
\text { students: } \\
\text { - to listen to the teacher } \\
\text { - to work with individual tasks } \\
\text { - to work in small groups } \\
\text { to discuss with the whole class? }\end{array}$ & $\begin{array}{l}30 \% \\
70 \% \\
80 \% \\
\\
20 \% \\
30 \% \\
30 \% \\
20 \%\end{array}$ \\
\hline
\end{tabular}

Table 4. Answers of the questionnaire by the students.

\begin{tabular}{|l|l|l|}
\hline & \multicolumn{1}{|c|}{ Questions } & \multicolumn{1}{c|}{ Students' answers } \\
\hline 1 & What did you like (if you liked anything)? & $\begin{array}{l}\text { Group work, creative activities, role play, simulation, } \\
\text { linguistic games, personal experiences, communica- } \\
\text { tion with the teacher. }\end{array}$ \\
\hline 2 & What didn't you like (if anything)? & $\begin{array}{l}\text { Noise when working in groups, the small space in the } \\
\text { classroom. }\end{array}$ \\
\hline 3 & What was it that surprised you (if anything)? & We knew how to do so many things. \\
\hline 4 & What did you learn from that lesson (if anything)? & $\begin{array}{l}90 \% \text { of the students say that they learned to do } \\
\text { many things. }\end{array}$ \\
\hline
\end{tabular}


Daniela TAMO, Aljula JUBANI, Mimoza GJOKUTAJ. New Dimensions of Teaching and Learning "By Doing" in the Global Context of Education

5. Assess the lesson by using the numbers from 1 to 4 .

\begin{tabular}{|c|c|c|c|}
\hline $\begin{array}{c}\text { I liked the lesson very } \\
\text { much }\end{array}$ & I liked the lesson & I didn't like the lesson & I didn't like the lesson at all \\
\hline $4-80 \%$ & $3-20 \%$ & 2 & 1 \\
\hline
\end{tabular}

\section{Discussion}

Inclusion of the global education philosophy in the Albanian school practice went through some steps involving curricula updates, training of experts and teachers, drafting of curricula materials and their piloting. The process was extended in a wide variety of schools, courses and teachers. Teachers and students report they consider this practice successful, considering it as leading to improvement of the teaching and learning quality, helping in establishment of civic and democratic values lacked in the Albanian schools. In addition, interviews with teachers, their opinions, and observations show that the organized activities helped not only in increasing knowledge, but even in terms of practicing practical and affective skills.

The activities were obviously suitable for students' intellectual development. The activities were largely assessed as positive by the teachers. The expected problems with physical space did not represent any impassable walls. The activities fulfilled the current objectives of the curriculum, and enriched Global Education with new elements. Their application led unavoidably to an inter-subject relationship. A teacher of the Albanian language said: "Links were established between different subjects like language, literature, geography, drawing, etc.", while another one admits that Global Education is giving various subjects in school a more human dimension, developing an inter-subject understanding and integration of all the subjects in the real life.

Interviews with teachers and students show that the curriculum offers opportunities for developing knowledge, concepts, and information in terms of civic skills and attitudes. Students feel that the knowledge they obtain through direct participation in class are more sustainable than those obtained through oral information obtained from the teachers. They appreciate the fact that such classes give students opportunities to participate actively. Even students, who would normally not participate, find more space and freedom in these classes to express themselves, and to give their contribution. One of the students expressed his surprise "How come even the weak students answered so well? Even a student, who does not care about learning, participated".

Some students are happy with their participation in simple research processes, which gave them the opportunity "to learn even from other people, their parents, relatives, and even from newspapers". This helps them address topics and ideas, which would not have been addressed and even mentioned by teachers in a traditional setting. In an interview with a student about civic education, he said: "We learned things that the teacher had not told us. For example, we learned that adults should respect our rights and ask us what we like and what we dislike, etc."

In addition, students noted that they "feel good during the class", and "express themselves better and more easily". They also say that they cooperate better now as a team. Many students think that the activities helped them practice new skills, and that especially group work activities helped them identify their difficulties and weaknesses. They, for instance, identified a need for improving their listening skills.

Students were often surprised. They were surprised to find out that learning could be even entertaining at the same time. "It reminded us of the games we played when we were little" says a student, while another one adds: "The class was special. We did not expect it to be 
PROBLEMS

OF EDUCATION

IN THE $21^{\text {st }}$ CENTURY

Volume 44, 2012

that entertaining and fun. I now look forward to the next class". Encouraged by such activities, students revealed their talents, skills, potential, and understanding skills, which they were not aware that they had already had.

Students perceive their teachers in a different way now. They have constantly expressed their appreciation for their teachers' skills in the interviews and have more trust in their teachers. Students, even the shyest ones are now "less embarrassed and not afraid of the teacher approaching them using insulting words about their thoughts".

Before the test, a teacher expressed her concern as follows: "Will it be easy for students to adapt to this new way of teaching? Will all students participate?" After the test, the same teacher said: "Students did adapt very quickly to the new teaching approach. They even exceeded my expectations proving that my concerns were not justified".

Teachers noted that students are capable of obtaining new information and generalizing their experiences helping thus in transferring information not only from the teachers to their students, but also vice-versa. One of the teachers admitted that she did learn from her students in several occasions. "I have to admit, - she says, - that I have been wrong in considering myself the only source of information in class. It is surprising, but I have learned a lot from my students during these activities".

Teachers became more confident in their role as developers and facilitators of the learning activities. Teachers also admit that in organizing these activities, they saw themselves more as facilitators, and that they had to share their responsibilities with their students, leaving behind the idea that they are the only people responsible for reaching the learning objectives. At the beginning, this caused a concern and a real feeling of responsibility, as they had to change the way they saw their authority in class. Such a change was difficult in the Albanian context, especially in certain areas, where the patriarchal mentality is still strong. This was obvious in the interviews we had with teachers before the test. Their answers clearly showed that some of them still considered themselves the transmitter of knowledge in class.

In addition, the interviews and questionnaires filled during the preparatory pilot phase showed that almost all the teachers were anxious about the difficulties they anticipated that they would have with interactive learning and students' participation; students' capability and will to work as a team; the level of adaptation of the activities to the curriculum objectives; the level of the adaptation of the classroom to such activities, especially physical space for learning processes that require a spacious environment; and the time available for the activities.

A simple calculation made for the subject of mathematics showed that about $25 \%$ of the class was led by the teacher, while $75 \%$ by the students themselves. It was also found that students spend as an average: $16 \%$ of their time listening; $33 \%$ for individual work, and $30 \%$ for group work; $21 \%$ for discussions with the entire class. These figures show clearly the progress made by teachers in the learning process. They are in better control of the situation and clearer about what happens with certain groups, and even with certain individual students.

Observations show that some teachers had difficulties with going beyond the established teaching tradition, and sometimes they made steps backward. It has to be noted how concerned and limited a teacher feels about the idea of being a facilitator in the learning process. They express fear about not being able to do their job properly, while others feel like they "have lost something important". However, teachers played an important role in creating a more democratic, and a more human climate in the classroom for motivating and mobilizing their students.

Assessing the effectiveness of learning through activities, especially through a more active role of the students in the learning process, a teacher of civil education said: "Students understand better the current issues; they take individual initiatives, and develop their respect for their own and other people's rights, feelings, and values". Likewise, a teacher of the Albanian language said: "The topic and new information was transmitted through students' activities and 
Daniela TAMO, Aljula JUBANI, Mimoza GJOKUTAJ. New Dimensions of Teaching and Learning "By Doing" in the Global Context of Education

exchange of their experience in class". Teachers also made use of other premises for organizing activities that required more space. They used the school corridors, halls, and libraries.

Despite the achievements made, teachers still have some difficulties with leading their activities. Some of them "despite their good will, have difficulties with dividing their class into groups, summarizing their activities". There are also some teachers, who have difficulties with making students participate actively in summarizing the activities. They think that it is them who should say the final word and the ultimate truth in class.

It must be said that there have been different reactions to Global Education from directors, teachers and parents. Some concern was also expressed in the first interviews with the teachers involved in the project about a potential refusal of this new approach. When the activities were actually carried out, most of the directors and teachers did support Global Education in their schools despite their initial scepticism. Many teachers expressed their willingness to participate in Global Education activities. In some schools, directors organized seminars, where they introduced the Global Education theory and methodology, as well as the results of the pilot phase. Such a reaction raised interest among the rest of the teachers for participating in the project.

The impact of the pilot phase is also observed in the use of certain terms by teachers and students like the "Global Education class", which was also reflected on their communication in their families. Such an impact made parents play a more active role in helping students prepare the necessary tools for the Global Education classes in school.

\section{Conclusions}

There are some conclusions coming out as a result of piloting the Global Education philosophy in the Albanian school through an amended curriculum, model classes for different subjects, and training of teachers and directors. These conclusions can be grouped as below:

\section{A. Enrichment of the school curriculum with contemporary objectives, which convey:}

Rich perspectives as an objective that helps students realize that their view of the world is formed based both on their experience, and their culture, nationality, gender, and generation.

Facts which help students learn the main geographic, political, social, and economic facts about the world.

Participation, which helps students develop and practice the skills needed for active and democratic participation in the community.

Communication, which is one of the objectives that helps students develop effective communication skills.

Cultural growth, which is an objective that helps students develop their respect for the rights, feelings, main values and dignity of other people, and living beings.

Study skills is another objective that helps students develop study skills, including planning, organizing, and carrying out independent surveys, and evaluating their findings.

Feelings, which help students understand the thoughts and feelings of other people, especially of those who belong to a different culture, nationality, race, sex, and generation.

Critical skills an objective that helps students develop analytical and critical thinking skills, so that they can identify trends, and have their own judgment about what they learn from the media, or what they hear in the classroom.

Self-awareness, which is an objective that helps students become aware of their strengths and weaknesses, tendencies and prejudice, so that they can work on building a positive image of themselves.

Community helps students understand the humanity needs, talents, and aspiration. 
PROBLEMS

OF EDUCATION

IN THE $21^{\text {st }}$ CENTURY

Volume 44, 2012

Relationships help students develop the views and skills needed to establish and maintain reasonable relationships.

Cooperation is another objective that helps students recognize the fact that relationships between individuals, groups, and societies need to be based on the principle of equality.

Alternative visions are related with introducing the students with alternative visions of the reality and alternative strategies for achieving personal and societal transformation.

\section{B. The suitability of Global Education for basic education}

Piloting of Global Education activities enabled this philosophy to adapt to the Albanian education. Thus, there is now a better understanding of many teaching approaches proven to be effective in improving the learning environment, and many model activities were introduced showing how the school programs can be drafted and reviewed in a way that they contain new methodologies and strategies for reaching the objectives of teaching in basic education, and a variety of learning methods that encourage equality, improve the teaching quality, and introduce the new concept of teachers as facilitators, etc.

\section{Characteristics of a Global Education activity}

It was found that a teaching activity (model class) that respects the Global Education principles has the following characteristics: the lesson content addresses one of the four dimensions of Global Education: space, time, problems, and the internal dimension; methodology is in harmony with the activity message, e.g. an activity about cooperation is carried out collectively; student's participation and responsibility for reaching their objectives is high, and the teacher plays a minor and assisting role; the activity tries to develop students' values and skills based on the knowledge they already have. Students are involved at many levels, i.e. at the intellectual, emotional, social, spiritual, and physical level; the activity urges students to find creative solutions to problems; the activity develops several skills like listening through communication, observation, cooperation, negotiation, decision-making, problem-solution, critical reflection, perspective, and anticipation; the activity is important for the students' lives, and suitable to their level of development.

\section{Characteristics of teachers organizing future-oriented teaching activities}

A teacher organizing his/her class in a future-oriented way is more focused on the global, rather than on the ethnical side. The teachers of the future take into consideration culture and perspective are future-oriented, play the role of a facilitator, have great confidence in human potential, apply a variety of teaching approaches in class, and see learning as a lifelong process.

\section{References}

Banks, J. A. (2004). Diversity and Citizenship Education: Global Perspectives. Jossey Bass, San Francisko.

Banks, J. A. (2009 February). Educating Global Citizens in a Diverse World. New Horizons for Learning.

Banks, J. A., Cookson, P., Gay, G., Hawley, W. D., Irvine, J. J., Nieto, S. (2001). Diversity within unity: Essential principles for teaching and learning in a multicultural society. Seattle: Center for Multicultural Education, University of Washington.

Chapman, W. D., Carrier, A. C. (1990). Improving Educational Quality: a Global Perspective. Greenwood Press. New York. 
Daniela TAMO, Aljula JUBANI, Mimoza GJOKUTAJ. New Dimensions of Teaching and Learning "By Doing" in the Global Context of Education

Dautaj, A. (1999, January). "Edukimi Global në Shqipëri”, newspaper "Mësuesi”.

$\mid$\begin{tabular}{l} 
PROBLEMS \\
OF EDUCATION \\
IN THE 21 $1^{\text {st }}$ CENTURY \\
Volume 44, 2012 \\
\hline 91
\end{tabular}

Davies, L. (2009, August 27). “Global Citizenship Education.” Encyclopedia of Peace Education. New York: Teachers College.

Fernekes, W. R., Gaudelli, W. (2004). Teaching about Global Human Rights for Global Citizenship: Action Research in the Social Studies Curriculum. The Social Studies, 95 (1), 16-26.

Foley, G. (2004). The dimensions of Adult Learning: Adult Education and Training in a Global Era. Open University Press, Maidenhead, England.

Mccabe, L. T. (1997). Global Perspective Development. Education, 118 (1).

Noddings, N. (2005). Educating Citizens for Global Awareness. Teachers College Press, New York.

Gjokutaj, M. (2001). Teknologji të reja mësimore - Edukimi global. Journal "Mprehtësi”, 2.

Ministry of Education and Science (Albania) (2004). "Reforma Arsimore në Shqipëri”. Retrieved from http://www.mash.gov.al

Tucker, J. (1986). Global awareness through global education. In Freeman, R. Promising Practices in Global Education: A handbook of Case Studies. New York: National Council on Foreign Language and International Studies, p. 66.

Advised by Elida Tabaku, Tirana University, Tirana, Albania

Received: May 04, 2012

Accepted: June 15, 2012

\begin{tabular}{|ll}
\hline Daniela Tamo & $\begin{array}{l}\text { Associate Professor, Lecturer, English Department, Faculty of Foreign Languag- } \\
\text { es, Tirana University, Albania. } \\
\text { E-mail: danielatamo@gmail.com }\end{array}$ \\
\hline Aljula Jubani & $\begin{array}{l}\text { Associate Professor, Lecturer, Department of the Albanian Language, Faculty of } \\
\text { History and Philology, Tirana University, Albania. } \\
\text { E-mail: aljulajubani@yahoo.com }\end{array}$ \\
\hline Mimoza Gjokutaj & $\begin{array}{l}\text { Professor, Lecturer, Department of the Albanian Language, Faculty of History } \\
\text { and Philology, Tirana University, Albania. } \\
\text { E-mail: mgjokutaj@yahoo.com }\end{array}$
\end{tabular}

